\title{
Uses and Potential Abuses of "Negative Claims" in the EU: The Urgent Need for Better Regulation
}

\begin{abstract}
Ignacio Carreño* and Paolo Vergano**
"Negative claims" can be defined as claims indicating that certain ingredients, nutrients or substances are not present in a foodstuff. Legitimate uses of regulated negative claims in the EU include some nutrition claims and "gluten-free" claims. Some EU Member States have legislated on "GM-free" claims. The article describes in more detail some cases (i.e., BPA-free, MSG-free, Aspartame-free and palm oil-free), where negative claims are used with an implied message that whatever is used instead of the often "demonised" substance is safer, healthier or greener. The article argues that EU and EU Member States' legislators and regulators should ensure that consumers are not misled by astute marketing techniques that have no informative agendas, but simply aim at denigrating certain products in order to promote "free-from" products. This issue is particularly timely and important given the imminent application of the EU's Food Information Regulation and the additional costs that it will impose on the industry in the name of providing complete, reliable and evidence-based information to consumers.
\end{abstract}

\section{Introduction}

What do bisphenol A, aspartame, monosodium glutamate, GMOs, palm oil and other substances or products have in common? Having caused some stirs within the public for alleged safety, environmental or nutritional reasons, they have all been the object of voluntary "negative claims". A wealth of products that do not contain these (and other) substances often carry a label informing the consumers that they are "free from" the substance or product at issue. "No additives", "no preservatives" and "no artificial colorants" statements on food products are further examples of this plethora of "negative claims" on food labels. While certain voluntary "freefrom" claims can be made in the EU, inter alia, "fatfree" and "gluten-free", voluntary negative labelling strategies raise significant legal and policy controversy.

\footnotetext{
* Senior Associate, FratiniVergano - European Lawyers, www.fratinivergano.eu.

** Partner, FratiniVergano - European Lawyers, www.fratinivergano.eu.
}

This article looks first at the legitimate uses of "negative claims" in the EU. EU Member States' legislation and schemes on voluntary "negative claims" are discussed looking at the "GM-free" legislation and schemes in France and Germany. Voluntary unregulated negative claims are addressed in a chapter on "clean labelling". The article describes in detail some examples for potential abuses of negative claims (i.e., BPA-free, MSG-free, aspartame-free and palm oilfree). The different voluntary "negative claims" are assessed, in particular under EU rules on nutrition claims, administrative practices in some EU Member States and rules on misleading advertising. Private initiatives are analysed, such as an example of "pejorative" claims in France. The article discusses whether legislative and/or regulatory processes should be triggered in order to adopt new rules at the EU level for purposes of preventing or effectively countering damaging "negative claims". There is also an ongoing trend in the EU to label foodstuffs as "free from", which is understood by many consumers as implying that these products are a healthier choice. The article concludes that EU and EU Member States' legislators and regulators, while they impose costly new rules on producers, should also ensure that con- 
sumers are not misled by astute marketing techniques that have no informative agendas, but simply aim at denigrating certain products in order to promote others or to convince consumers that what is "free-from" a certain substance is a better, healthier or greener product.

Negative claims have also been addressed in three recent press articles in renowned British, German and Spanish newspapers, which perfectly describe this trend. The article "Free from sin" published in the Süddeutsche Zeitung concludes that "Bio" was yesterday and today expensive products are labelled with the salvation-promising word "free": lactosefree, fructose-free, gluten-free. ${ }^{1}$ The article "Gluten free does not mean healthier" published in El Pais concludes that as soon as something new appears, the industry exploits it and helps spreading its benefits, whether they are real or not. Although for a while everything was "light", we have passed to the trend of the natural, the healthy and the "free-from". 2 The Guardian concludes that "by marketing products as 'free from' supermarkets are playing on people's fears, which are based on the rumours circulated about these substances." ${ }^{3}$

\section{The legitimate uses of "negative claims"}

The legislative framework in the EU for the labelling of foodstuffs is set out in its general food law and in specific Directives and Regulations. The general principle has been established in Article 16 of Regulation
(EC) No 178/2002 of the European Parliament and of the Council laying down the general principles and requirements of food law, ${ }^{4}$ which requires that the labelling, advertising and presentation of food or feed, including their shape, appearance or packaging, the packaging materials used, the manner in which they are arranged and the setting in which they are displayed, and the information which is made available about them through whatever medium, shall not mislead consumers.

More specific rules have been set out in Directive 2000/13/EC of the European Parliament and of the Council on the approximation of the laws of the Member States relating to the labelling, presentation and advertising of foodstuffs (hereinafter, Directive 2000/13); ${ }^{5}$ Council Directive 90/496/EEC on nutrition labelling for foodstuffs; ${ }^{6}$ and Regulation (EU) No 1169/2011 of the European Parliament and of the Council on the provision of food information to consumers (hereinafter, the FIR). ${ }^{7}$ Regulation (EC) No 1924/2006 of the European Parliament and of the Council on nutrition and health claims made on food (hereinafter, Regulation (EC) No 1924/2006) $)^{8}$ and Directive 2006/114/EC of the European Parliament and of the Council concerning misleading and comparative advertising ${ }^{9}$ are also of relevance.

As will be seen throughout this article, no EU measures (besides some rules on certain nutrients and gluten discussed below) explicitly address voluntary "negative claims", which, for purposes of this article, are defined as claims made in the form of a nutrition claim (i.e., in form of logos or other pictorial, graphic or symbolic representation) that inform that cer-

1 Evelyn Roll, "Frei von Sünde", Süddeutsche Zeitung, 11/12 January 2014 (in the weekend edition).

2 Raquel Vidales, "Sin gluten no quiere decir más sano", El Pais 11 April 2014. Available on the Internet at: http://sociedad.elpais.com/sociedad/2014/04/11/actualidad/ 1397242694_867535.html (last accessed on 15 November 2014).

3 Supermarkets cash in on unfounded fears about food and health, The Guardian, 9 June 2013. Available on the Internet at: http://www.theguardian.com/science/blog/2013/may/09/ supermarkets-unfounded-fears-food-health (last accessed on 15 November 2014) See also: Rick Pendrous, "Supermarkets must stop scaremongering, say scientists", Foodmanufacture.co.uk, 1 May 2013. Available on the Internet at: http://www.foodmanufacture.co .uk/Food-Safety/Supermarkets-must-stop-scaremongering-say -scientists (last accessed on 15 November 2014).

4 Regulation (EC) No 178/2002 of the European Parliament and of the Council laying down the general principles and requirements of food law, establishing the European Food Safety Authority and laying down procedures in matters of food safety, OJ 2002 L 31/1.

5 OJ 2000 L 109/29 (Repealed by the FIR, but end of validity 13.12.2014)

6 OJ 1990 L 276/40 (Repealed by the FIR, but end of validity 13.12.2014).

7 Full title: Regulation (EU) No 1169/2011 of the European Parliament and of the Council on the provision of food information to consumers, amending Regulations (EC) No 1924/2006 and (EC) No 1925/2006 of the European Parliament and of the Council, and repealing Commission Directive 87/250/EEC, Council Directive 90/496/EEC, Commission Directive 1999/10/EC, Directive 2000/13/EC of the European Parliament and of the Council, Commission Directives 2002/67/EC and 2008/5/EC and Commission Regulation (EC) No 608/2004, OJ 2011 L 304/18. O) 2006 L 404/9

9 (376, repealing Council Directive 84/450/EEC relating to the approximation of the laws, regulations and administrative provisions of the Member States concerning misleading advertising, OJ 1984 L 250/17. 
tain ingredient, nutrient or other substance is not present in a product.

\section{1. "Negative" nutrition claims}

References to general, non-specific benefits of a nutrient or food for overall good health or health-related well-being must comply with Regulation (EC) No 1924/2006. This Regulation also allows the use of "naturally" or "natural" to precede claims such as "sugars-free" or "high protein" when the food naturally meets the condition(s) laid down in the Annex to the regulation for the use of a nutrition claim.

Under Article 6 of Regulation (EC) No 1924/2006, nutrition and health claims must be based on and substantiated by generally accepted scientific evidence; and food business operators making nutrition or health claims must justify the use of the claims. The Annex to Regulation (EC) No 1924/2006 lists five different "negative" (i.e., "-free") nutrition claims : (1) A claim that a food is "energy-free" may only be made where the product does not contain more than $4 \mathrm{kcal}$ $(17 \mathrm{~kJ}) / 100 \mathrm{ml} ;(2)$ A claim that a food is "fat-free" may only be made where the product contains no more than $0.5 \mathrm{~g}$ of fat per $100 \mathrm{~g}$ or $100 \mathrm{ml}$; (3) A claim that a food is "saturated fat-free" may only be made where the sum of saturated fat and trans-fatty acids does not exceed $0.1 \mathrm{~g}$ of saturated fat per $100 \mathrm{~g}$ or 10oml; (4) A claim that a food is "sugars-free" may only be made where the product contains no more than $0.5 \mathrm{~g}$ of sugars per $100 \mathrm{~g}$ or 10oml; and (5) A claim that a food is "sodium-free" or "salt-free" may only be made where the product contains no more than $0.005 \mathrm{~g}$ of sodium, or the equivalent value for salt, per $100 \mathrm{~g}$.

10 OJ 2009 L 16/3.

11 For the sake of clarity and consistency, the EU established, in Regulation (EU) No 609/2013 (OJ 2013 L 181/35), that rules on the use of the statements "gluten-free" and "very low gluten" should be in the future regulated under the FIR, in particular under Article 21 of the FIR on the labelling of certain substances or products causing allergies or intolerances listed in Annex II to the FIR. Article 36(3)d) of the FIR provides that the European Commission shall adopt implementing acts in relation to the voluntary information on the absence or reduced presence of gluten in food. Thus, the Commission has adopted Delegated Regulation (EU) No 1155/2013 amending the FIR as regards information on the absence or reduced presence of gluten in food, OJ 2013 L 306/7.

12 OJ 2014 L 228/5.

13 OJ 2006 L 401/1.

\section{2. "Gluten-free" and "lactose-free" claims}

People with celiac disease suffering from a permanent intolerance to gluten are considered to be a specific group of the population, which needs foodstuffs intended for particular nutritional uses that are intended to satisfy their particular nutritional requirements. The food industry has over time developed a range of products presented as "gluten-free" or other similar terms. Differences between national provisions in EU Member States concerning the conditions for the use of such product descriptions have resulted in the adoption of harmonised rules on the use of the claims "gluten-free" and "very low gluten". Article 3 of Commission Regulation (EC) No 41/2009 concerning the composition and labelling of foodstuffs suitable for people intolerant to gluten ${ }^{10}$ sets out that foodstuffs for people intolerant to gluten, consisting of or containing one or more ingredients made from wheat, rye, barley, oats or their crossbred varieties, which have been especially processed to reduce gluten, must not contain a level of gluten exceeding $100 \mathrm{mg} / \mathrm{kg}$ in the food as sold to the final consumer. Paragraph 2 of Article 3 establishes that the labelling, advertising and presentation of such products must bear the term "very low gluten" and that they may bear the term "gluten-free" if the gluten content does not exceed $20 \mathrm{mg} / \mathrm{kg}$ in the food as sold to the final consumer. ${ }^{11}$

Commission Implementing Regulation (EU) No $828 / 2014$ on the requirements for the provision of information to consumers on the absence or reduced presence of gluten in food, ${ }^{12}$ which applies from 20 July 2016, provides in recital 10 that it should also be possible for a food containing ingredients naturally free of gluten to bear terms indicating the absence of gluten, provided that the general conditions on fair information practices set out in Regulation (EU) No 1169/2011 are complied with. In particular, food information should not be misleading by suggesting that the food possesses special characteristics when in fact all similar foods possess such characteristics. The wording of the new implementing regulation suggests that one can say "naturally gluten free" when one adheres to fair information practices (i.e., the claim is evidence-based) and does not mislead (for example, mineral water may not be labelled as "naturally gluten free").

In this context, Commission Directive 2006/141/EC on infant formulae and follow-on formulae ${ }^{13}$ prohibits 
the use of ingredients containing gluten in the manufacture of such foodstuffs. The German Working Group of Experts of Food Chemistry of the Federal States and the Federal Office for the Protection of Consumers and Food Security (Arbeitskreis Lebensmittelchemischer Sachverständiger der Länder und des Bundesamtes für Verbraucherschutz und Lebensmittelsicherheit, or ALS, in its German acronym) was asked how a "glutenfree" claim can be made against this background and how the indication of "gluten-free" can be formulated on such foods? In its opinion No. 2011/57, ${ }^{14}$ the ALS held that a "gluten-free" claim on infant formulae and follow-on formulae is misleading in accordance with 『11 Section 1, Sentence 2, No. 3 of the German Food and Feed Code (LFGB in its German acronym) as it constitutes an advertisement with a certainty. The ALS stated that consumers can be informed, for example, through statements such as "produced without glutencontaining ingredients according to the law".

Recital 42 of Regulation (EU) No 609/2013 acknowledges that labelling and compositional rules indicating the absence or reduced presence of lactose in food are currently not harmonised at the EU level. It calls for the adoption of harmonised rules on "lactose-free" claims. For the sake of clarity and consistency, the establishment of rules on the use of statements indicating the absence or reduced presence of lactose in food should be regulated under the FIR, taking into account the Scientific Opinion of the European Food Safety Authority (hereinafter, EFSA) of 10 September 2010 on lactose thresholds in lactose intolerance and galactosaemia. ${ }^{15}$ In fact, this appears reasonable as many "lactose-free" products are on the market and they are advertised as healthier than those containing lactose.

\section{EU Member State legislation on "negative claims" ("GM-free" claims in France and Germany)}

Regulation (EC) No 1829/2003 of the European Parliament and of the Council on genetically modified food and feed ${ }^{16}$ and Regulation (EC) No 1830/2003 of the European Parliament and of the Council concerning the traceability and labelling of genetically modified organisms and the traceability of food and feed products produced from genetically modified organisms and amending Directive 2001/18/EC ${ }^{17}$ establish detailed requirements for the labelling of ge- netically modified food and feed. In particular, food containing genetically modified materials at a level above the $0.9 \%$ threshold must be labelled as such. However, EU legislation does not establish requirements nor does it forbid the use of "GM-free" labels signalling that foodstuffs do not contain GM crops, or were produced not using GMOs. Such labels are being developed in several EU Member States. ${ }^{18}$

\section{Legislation on "GMO-free" claims in France}

France adopted on 30 January 2012 Decree no. 2012-128 concerning the voluntary labelling of foodstuffs originating from production chains qualified as "GMO-free" (hereinafter, Decree no. 2012-128). ${ }^{19}$ The rules contained therein implement the provision in the French Environmental Code recognising the freedom to produce and consume products either with or without GMOs. ${ }^{20}$

Decree no. 2012-128 lays down the specific GMOfree claims foodstuffs may carry when placed on the market. In relevant part, Decree no. 2012-128 identifies three categories of ingredients that may permit GMO-free claims (i.e., ingredients from vegetable origin; ingredients from livestock; and ingredients from apiculture) and lays down requirements applicable to each. Ingredients from vegetable origin may car-

14 The opinion of the ALS is available on the Internet at: http://www .bvl.bund.de/SharedDocs/Downloads/01_Lebensmittel/ALS_ALTS/ ALS_Stellungnahmen_98_Sitzung_2011.pdf?_blob

$=$ publicationFile--amp-v=2 (last accessed on 15 November 2014).

15 EFSA Journal 2010;8(9):1777. doi:10.2903/j.efsa.2010.1777.

16 OJ 2003 L 268/1.

17 OJ 2003 L 268/24.

18 See the answer given by Commissioner Borg on behalf of the European Commission to the Parliamentary question P-009834/2013 of 26 September 2013. Available on the Internet at: http://www.europarl.europa.eu/sides/getAllAnswers.do ?reference $=\mathrm{P}-2013-009834$ \&language $=\mathrm{EN}$ (last accessed on 15 November 2014)

19 Décret no. 2012-128 du 30 janvier 2012 relatif à l'étiquetage des denrées alimentaires issues de filières qualifiées "sans organismes génétiquement modifies"). JORF n²6/2012 p. 1770, texte n²7.

20 Art. L. 531-2-1 of the French Environmental Code, introduced by law number 2008-595 of 25 June 2008, concerning genetically modified organisms. Available on the Internet at: http://www.legifrance.gouv.fr/affichCodeArticle.do;jsessionid =A2D9B3B486E062EDB2F74104D1838D27.tpdjo02v_2 ?cidTexte=LEGITEXT000006074220\&idArticle $=$ LEGIARTI000019070290\&dateTexte $=20140505 \&$ categorieLien $=\mathrm{id}$ \#LEIARTI000019070290 (last accessed on 15 November 2014). 
ry the "GMO-free" claim provided they have not been genetically modified or they have been obtained from feedstock that is, in no more than a $0.1 \%$ proportion, genetically modified (and provided the presence of this proportion be adventitious and technically unavoidable).$^{21}$ Ingredients from apiculture may be labelled as "GMO-free within a $3 \mathrm{~km}$ range" provided they originate from hives placed where nectar and pollen sources, as well as any complementary food for bees, located within a $3 \mathrm{~km}$ range, are GMO-free. ${ }^{22}$ Decree no. 2012-128 establishes, inter alia, that the GMO-free claims outlined above may not advertise organoleptic, nutritional, health or environmental properties arising from the fact that the concerned products are GMO-free. ${ }^{23}$ There is no harmonised "GMO-free" labelling scheme or logo in France. This results in a number of private operators ${ }^{24}$ affixing different "GMO-free" logos to their products' labels.

\section{Regulated voluntary "GM-free" labelling scheme in Germany}

The regulation of the labelling of genetically modified foods throughout the EU is perceived by many German consumers to be incomplete because, when shopping, they cannot recognise whether dairy products, eggs or meat have been obtained from animals that have received genetically modified feed. ${ }^{25}$ To close this gap in Germany, the regulation of a voluntary "GM-free" label for foods was introduced.

\footnotetext{
21 Art. 3 of Decree no. 2012-128.

22 Art. 7 of Decree no. 2012-128.

23 Art. 8 of Decree no. 2012-128.

24 Such as Auchan, Bonduelle, Carrefour and Casino.

25 Available on the Internet at: http://www.bmel.de/DE/Ernaehrung/ Kennzeichnung/OhneGentechnik/_Texte/

OhneGentechnikKennzeichnung. html (last accessed on 15 November 2014).

26 Gesetz zur Durchführung der Verordnungen der Europäischen Gemeinschaft oder der Europäischen Union auf dem Gebiet der Gentechnik und über die Kennzeichnung ohne Anwendung gentechnischer Verfahren hergestellter Lebensmittel vom 22 Juni 2004 (BGBI. I S. 1244)

27 Art. $3 \mathrm{a}(2)$ of the EGDGG.

28 Art. $3 \mathrm{a}(3)$ of the EGDGG.

29 Art. $3 \mathrm{a}(4)$ of the EGDGG.

30 Art. $3 \mathrm{a}(5)$ of the EGDGG

31 Available on the Internet at: http://www.bmel.de/DE/Ernaehrung/ Kennzeichnung/OhneGentechnik/ Texte/

OhneGentechnikKennzeichnung.html (last accessed on 15 November 2014).
}

Article 3a(1) of the German Law implementing regulations of the European Union in the field of genetic engineering and on the labelling of food produced without the use of genetic engineering techniques (hereinafter EGDGG in its German acronym) ${ }^{26}$ sets out that a food may be placed on the market or advertised with a sign, which points to the manufacture of the food without the use of genetic engineering methods, when certain requirements are adhered to. Article 3a(1) also provides that only a "GM-free" claim may be used.

The EGDGG sets out that no foods and food ingredients must be used, which are labelled as foods that are intended for final consumers or mass caterers and that contain or consist of GMOs; or are produced from or contain ingredients produced from GMOs. ${ }^{27}$ No food and food ingredients may be used, which fall within the scope of Regulation (EC) No $1829 / 2003$, unless foods containing material that contains, consists of or is produced from GMOs in a proportion no higher than $0.9 \%$ of the food ingredients considered individually or food consisting of a single ingredient, provided that this presence is adventitious or technically unavoidable. ${ }^{28}$ In the case of a food or a food ingredient of animal origin, the animal may not have been fed with feed labelled as GMOs for feed use, feed containing or consisting of GMOs, feed produced from GMOs. ${ }^{29}$ For preparing, handling, processing or mixing of a food or food ingredient, no food, food ingredients, processing aids and materials produced by a genetically modified organism must have been used. ${ }^{30}$ This means that to be labelled as "GM-free", no ingredients, food additives or processing aids, flavourings, vitamins, amino acids or enzymes produced with the help of genetically modified microorganisms may be used for food.

The German Federal Ministry of Food and Agriculture (BMEL in its German acronym) informs that within the "GM-free" labelling scheme, feed additives produced using genetically modified micro-organisms under controlled conditions in a closed system, are permitted to ensure, for example, a nutritionally balanced animal nutrition. Also impurities with GM food plants under $0.9 \%$ are permitted, assuming they are adventitious or inevitable, as EU labelling law establishes no labelling obligation under these circumstances. ${ }^{31}$ In August 2009, the "GM-free" logo, which is awarded by the "Foods without Genetic Modification Association" (Lebensmittel ohne Gentechnik e.V., VLOG), was presented to the public. The BMEL 
has transferred the trademark rights to use the seal to the association. ${ }^{32}$

\section{Voluntary unregulated "negative claims" - "clean labels"}

A number of products on the market bear claims like "no additives", "no preservatives" and "no artificial colourings". Some of these products are also often referred to as "clean label" products. ${ }^{33}$ There is no formal definition of "clean label", however usually products are included that make "clean claims" like on the absence of pesticides and agro-chemicals, GM ingredients, gluten, lactose and additives. The definition could also be stretched to halal and kosher logos, since to Muslim and Jewish followers this signals that certain banned ingredients are not included. ${ }^{34}$

Such claims are often made in the form of logos or other pictorial, graphic or symbolic representation, which resemble nutrition claims. It can be argued that if such "clean label" products are required by consumers and do not, inter alia, denigrate specific additives or other substances that competitors are using, they should not be illegal, if the information is correct and evidence-based. However, in certain cases, such claims may nevertheless mislead. The German ALS was asked whether drinks that contain sulphur dioxide due to a fruit wine component can be marketed with the claim "no preservatives". In its opinion No 2012/24, ${ }^{35}$ the ALS held that the claim "no preservatives" on such drinks, which at the same time state "contains sulphites" (which is required by the FIR when the presence of the allergen sulphur dioxide is higher than $10 \mathrm{mg}$ ) is contradictory and therefore not possible.

It has also been reported that the proliferation in natural labels and logos is progressively leading to consumer distrust and that there is a concern that "clean labels" may follow the same route and consumers may turn to food products that are free-from such claims.

\section{Potential abuses of negative claims? Some examples}

The question is whether certain voluntary "negative claims", aimed at denigrating competing products and/or promoting other products by implying that whatever is used as an ingredient or nutrient is better, healthier or environmentally greener than what is not used, are legal. The chemical bisphenol A used in food packaging materials, the flavour enhancer monosodium glutamate, the sweetener aspartame and palm oil have all been subject to "negative claims" on competing products, which affix the respective "free-from" claims on their packaging.

\section{Bisphenol a-free}

Bisphenol A (hereinafter, BPA) is used as a protective lining on the inside of metal-based food and beverage cans and in the manufacturing of hard, transparent and heat-resistant plastic material called polycarbonate in order to replace glass containers for food and electronic products, including baby bottles. ${ }^{36}$ The controversy surrounding BPA began in the early 1990 s when it was discovered that BPA was migrating from the plastic (polycarbonate) laboratory bottles into the water used. ${ }^{37}$ Parents of newborns and small children have recently been confronted with labels indicating that their purchases of a baby bot-

32 Ohne Gentechnik-Siegel: Mehr Transparenz und Wahlfreiheit beim Lebensmitteleinkauf. Available on the Internet at: Idem.

33 Elaine Watson, "Natural \& Clean Label Trends 2013: How clean is your label? And can GMOs ever belong in "natural" products?" Confectionery News, 24 May 2013. Available on the Internet at: http://www.foodnavigator-usa.com/Markets/Natural-Clean-Label -Trends-2013-How-clean-is-your-label-And-can-GMOs-ever -belong-in-natural-products (last accessed on 15 November 2014); Jess Halliday, "Consumers' views on natural and clean label terminology", Confectionery News, 21 June 2010. Available on the Internet at: http://www.confectionerynews.com/ Ingredients/Consumers-views-on-natural-and-clean-label -terminology (last accessed on 15 November 2014).

34 Annie-Rose Harrison-Dunn, "Free from "free-from": Are consumers getting clean label lethargy?", Food Navigator, 14 May 2014. Available on the Internet at: http://www.foodnavigator.com/ Market-Trends/Searching-for-a-label-free-from-free-from-claims (last accessed on 15 November 2014).

35 The opinion of the ALS (ALS Stellungnahmen in German) is available on the Internet at: http://www.bvl.bund.de/SharedDocs/ Downloads/01_Lebensmittel/ALS ALTS/ALS Stellungnahmen _100_Sitzung_2012.pdf?_blob=publicationFile\&v=2 (last accessed on 15 November 2014).

36 For a policy overview on BPA see: Alberto Alemanno, "The Fabulous Destiny of Bisphenol A (BPA)", European Journal of Risk Regulation (hereinafter, EJRR) 4/2010, pp. 397-400; Ragnar E. Lofstedt Risk versus Hazard - How to Regulate in the 21 st Centu ry, EJRR 2/2011, pp. 149-168; K. Aschenberger, P. Castello, E. Hoekstra, S. Karakitsios, S. Munn, S. Pakalin, and D. Sarigiannis, "Bisphenol A and Baby Bottles: Challenges and Perspectives" (Ispra: European Commission, Joint Research Centre 2010).

37 A. Krishnan, P. Strathis, S. Permuth, L. Tikes, and D. Feldman, "Bisphenol A: An Estrogenic Substance is Released from Polycarbonate Flasks during Autoclaving", 132 Endocrinology (1993), pp. 2279-2286. 
tles are now "BPA-free". ${ }^{38}$ When heated under certain conditions, small amounts of BPA can potentially leach out from food containers into foods and beverages, and be ingested. Although BPA is said to have low acute toxicity, it might also be a so-called "endocrine disruptor" which, according to some scientists, may cause adverse health effects in cases of chronic exposure. ${ }^{39}$ According to scientific research, a child's ability to eliminate BPA is built up during their first six months of its life. Their exposure to the substance is thus the highest during this period, especially if infant formula administered through such baby bottles is their only source of nutrition. ${ }^{40}$

The EFSA examined the existing research findings, but viewed them to be somewhat unreliable. ${ }^{41}$ The EFSA completed its full risk assessment of BPA in 2006 and set a Tolerable Daily Intake (TDI) of 0.05 milligrams/kilogram of body weight per day $(\mathrm{mg} / \mathrm{kg}$ bw/day) for BPA. EFSA also evaluated the intake of BPA through food and drink for adults, infants and children and found that they were all below the TDI. In 2008, EFSA's BPA panel took the view that BPA is safer than initially thought and suggested increasing the daily safety threshold of consumption by a factor of five. ${ }^{42}$ EFSA reviewed new scientific information on BPA in 2009, 2010 and 2011 and its experts concluded on each occasion that they could not identify any new evidence that would lead them to revise the TDI for BPA.

BPA was authorised in the EU by Commission Directive $2002 / 72 / \mathrm{EC}^{43}$ to be used as monomer and ad-

38 Tessa Fox, Esther Versluis and Marjolein B.A. van Asselt, "Regulating the Use of Bisphenol A in Baby and Children's Products in the European Union: Current Developments and Scenarios for the Regulatory Future", EJRR 1/2011, pp. 21-35.

39 Id

40 Available on the Internet: http://ec.europa.eu/dgs/health _consumer/dyna/consumervoice/create_cv.cfm?cv_id=716 (last accessed on 15 November 2014).

41 Ragnar E. Lofstedt, "Risk versus Hazard - How to Regulate in the 21 st Century", EJRR 2/2011, pp. 149-168: EFSA examined the research findings surrounding Bisphenol A on three separate occasions, most recently in 2010, eg., EFSA, "Scientific opinion of Bisphenol A; Evaluation of a study investigating its neurodevelopmental toxicity, review of recent scientific literature on its toxicity and advice on the Danish risk assessment of Bisphenol A", 1829 EFSA Journal (2010), pp.1-110.

42 EFSA, "Scientific opinion of the panel on food additives, flavourings, processing aids and materials in contact with food (AFC) related to toxicokinetics of Bisphenol A. Question EFSA -Q-2008-382", 759 EFSA Journal (2008), pp. 1-10.

43 Commission Directive 2002/72/EC relating to plastic materials and articles intended to come into contact with foodstuffs, OJ 2002 L 220/18. ditive for the manufacture of plastic materials and articles intended to come in contact with foodstuffs, together with a specific migration limit of $0.6 \mathrm{mg}$ per kilogram food (SML $(\mathrm{T})=0.6 \mathrm{mg} / \mathrm{kg})$. However, an EU-wide suspension of the manufacture of polycarbonate infant feeding bottles with BPA was adopted by Commission Directive 2011/8/EU amending Directive $2002 / 72 / \mathrm{EC}^{44}$ based on the precautionary principle set out in Article 7 of Regulation (EC) No 178/2002, which allows the provisional adoption of measures on the basis of available pertinent information pending an additional evaluation of risk. Directive 2011/8/EU further states that, even where the risk, notably to human health, has not yet been fully demonstrated, it is appropriate to reduce infants' exposure to BPA as much as reasonably achievable, until further scientific data is available to clarify the toxicological relevance of some observed effects of BPA. As of 1 June 2011, the temporary ban was extended to the placing on the market and the import into the EU of baby bottles containing BPA. Directive 2002/72/EC has been replaced since May 2011 by Regulation (EU) No 10/2011, ${ }^{45}$ which has maintained the ban of BPA in polycarbonate infant feeding bottles and kept the current restriction for BPA as a monomer with a specific migration limit of $0.6 \mathrm{mg}$ per kilogram food. ${ }^{46}$

Bans on the use of BPA for food packaging intended for young children have also been established by individual EU Member States, including Denmark, ${ }^{47}$ Sweden ${ }^{48}$ and Belgium. ${ }^{49}$ France adopted a law sus-

44 Commission Directive 2011/8/EU amending Directive 2002/72/EC as regards the restriction of use of Bisphenol $A$ in plastic infant feeding bottles, OJ 2011 L 26/11.

45 Commission Regulation (EU) No 10/2011 on plastic materials and articles intended to come into contact with food, OJ 2011 L 12/1.

46 See: DRAFT Scientific Opinion on the risks to public health related to the presence BPA in foodstuffs - Part: exposure assessment, Panel on Food Contact Materials, Enzymes, Flavourings and Processing Aids (CEF), European Food Safety Authority (EFSA).

47 Danish Order on food contact materials: Bekendtgørelse om fødevarekontaktmaterialer 579/2011 (§ 8, stk. 2). Available on the Internet at: https://www.retsinformation.dk/Forms/R0710.aspx?id =136917\&exp=1 (last accessed on 15 November 2014).

48 Regulation No 991/2012 of 20 December 2012 amending the Food Regulation No 813/2006, Svensk författningssamling (SFS), 4.1.2013, p.1.

49 Loi du 4 septembre 2012 modifiant la loi du 24 janvier 1977 relative à la protection de la santé des consommateurs en ce qui concerne les denrées alimentaires et les autres produits, visant à interdire le bisphénol A dans les contenants de denrées alimentaires publiée au Moniteur Belge le 24 septembre 2012. This amendment was based on the opinion of the Belgium Superior Health Council, issued on 3 November 2012 
pending the manufacturing, import, export and placing on the market of all food contact materials containing BPA. The French law has applied gradually since 1 January 2013 to materials coming into contact with food intended for children between 0 and 3 years of age and as of 1 January 2015 to all food contact materials. ${ }^{50}$ The French law goes much further than the harmonised EU legislation or other EU Member States' bans. It was adopted in response to reports published by the French Agency for Food, Environmental and Occupational Health Safety (hereinafter, ANSES), which deemed it necessary to replace BPA with other packaging materials. ${ }^{51}$ The reports conclude that there are detrimental health effects that have been proven in animals and are suspected in humans, even at low levels of exposure, and that these effects may also depend greatly on individuals being exposed during different phases of their development.

The European Commission has requested EFSA to review two reports on BPA following the recent publications by ANSES. In February 2012, following further consideration of new scientific studies, EFSA's CEF Panel (on Food Contact Materials, Enzymes, Flavourings and Processing Aids) decided to undertake a full re-evaluation of the human risks associated with exposure to BPA through the diet. The new opinion will review all the available data and scientific studies on dietary exposure published since EFSA's 2006 opinion. The Panel will further evaluate uncertainties about the possible relevance to human health of some BPA-related effects observed in rodents at low dose levels. In July 2013, EFSA launched a public consultation on the first part of its draft scientific opinion, specifically on its assessment of consumer exposure to BPA. EFSA's scientific experts provisionally concluded that, for all population groups, diet is the major source of exposure to BPA and exposure is lower than previously estimated by EFSA.

In January 2014, EFSA presented the second part of the draft opinion relating to the human health risks posed by exposure to BPA. In the draft opinion, EFSA identified likely adverse effects on the liver and kidney and effects on the mammary gland as being linked to exposure to the chemical and recommended that the current TDI be lowered from its current level to $0.005 \mathrm{mg} / \mathrm{kg} / \mathrm{bw} /$ day. EFSA also noted that uncertainties remained over a number of other health hazards and that the proposed TDI should be set on a temporary basis pending the outcome of research from the US National Toxicology Program (NTP), which will address many of these current uncertainties about the potential health effects of BPA. However, EFSA concluded that BPA poses a low health risk to consumers as exposure to the chemical is well below the temporary TDI ${ }^{52}$ and extended the deadline for its new risk assessment until the end of 2014.

Science on BPA is still divided and research is going on. It can be argued that "BPA-free" logos on plastic containers (both for adults or infants) do not help, inter alia, consumers to judge whether the alternatives used are safer.

\section{Monosodium glutamate-free}

The flavour enhancer monosodium glutamate (hereinafter, MSG) is added to processed foods, especially soups, sauces and sausages. Particularly in the UK, products are often marketed using "MSG-free" logos. The flavour enhancer has been criticised in recent years by anecdotal reports that it could contribute to a host of health problems, from hyperactivity in children to food allergies. ${ }^{53}$

A 1991 report by EFSA's predecessor, the European Community's Scientific Committee for Foods (hereinafter, SCF) ${ }^{54}$ reaffirmed MSG's safety and classified its acceptable daily intake as "not specified", the most favourable designation for a food ingredient. In addition, the SCF is quoted in saying that

50 LOI n² 2012-1442 du 24 décembre 2012 visant à la suspension de la fabrication, de l'importation, de l'exportation et de la mise sur le marché de tout conditionnement à vocation alimentaire contenant du bisphénol A, OJ of the French Republic (OJFR), 26.12.2012, text 2 of 154 .

51 Effets sanitaires du bisphénol A, Rapport d'expertise collective, Connaissances relatives aux usages du bisphénol A, Rapport d'étude, Septembre 2011. Available on the Internet at: http://www .anses.fr/sites/default/files/documents/CHIM-Ra-BisphenolA.pdf (last accessed on 15 November 2014).

52 Available on the Internet at: http://www.efsa.europa.eu/en/topics/ topic/bisphenol.htm?wtrl=01 and http://www.efsa.europa.eu/en/ press/news/140117.htm (last accessed on 15 November 2014).

53 MSG sales growth flags amid negative publicity of 3 October 2011. Available on the Internet at: http://www.foodmanufacture.co.uk/Ingredients/MSG-sales-growth -flags-amid-negative-publicity (last accessed on 15 November 2014).

54 First series of food additives of various technological functions (Opinion expressed on 18 May 1990, Directorate General Internal Market and Industrial Affairs, EUR 13416. Available on the Internet at: http://ec.europa.eu/food/fs/sc/scf/reports/scf_reports _25.pdf (last accessed on 15 November 2014). 
"iinnfants, including prematures, have been shown to metabolise glutamate as efficiently as adults and therefore do not display any special susceptibility to elevated oral intakes of glutamate". ${ }^{55}$ Article 4(1) of Regulation (EC) No 1333/2008 of the European Parliament and of the Council on food additives ${ }^{56}$ requires that only food additives included in the EU list in Annex II to the Regulation may be placed on the market as such and used in foods under the conditions of use specified therein. MSG is listed in Commission Regulation (EU) No 1129/2011 of 11 November 2011 amending Annex II to Regulation (EC) No 1333/2008 of the European Parliament and of the Council by establishing a Union list of food additives $^{57}$ as flavour enhancer E621, with a specific maximum level of $10 \mathrm{~g} / \mathrm{kg}$. In regulatory procedures for the establishment of the EU lists of additives, Members of the European Parliament argued that MSG "can provoke in certain cases nervous symptoms (decreased sensibility in neck, arms and back) and irregular heartbeat". ${ }^{58}$ However, albeit these concerns, the EU considers MSG to be safe and includes it in its list of food additives.

At the international level, the Codex General Standard for Food Additives (GSFA, Codex STAN 192-1995) sets out that MSG is a food additive that is included in Table 3, and as such may be used in a

55 Food Regulation: Law, Science, Policy, and Practice, By Neal D. Fortin, John Wiley \& Sons, 20 Sep 2011, chapter 7.3 food additives, 7.3.9 MSG.

56 OJ 2008 L 354/16.

57 OJ 2011 L 295/1.

58 Draft report (PE 355.470v01-00) "Food additives other than colours and sweeteners and Directive 94/35/EC on sweeteners for use in foodstuffs" of 12 May 2005, Proposal for a directive COM(2004)0650.

59 Available on the Internet at: http://www.codexalimentarius.net/ gsfaonline/additives/details.html?id=276 (last accessed on 15 November 2014).

60 WHO 1988. Toxicological Evaluation of Certain Food Additives. WHO Food Additives Series NO 22, Cambridge University Press.

61 Food safety New Zealand FSANZ Monosodium Glutamate (2003). A safety assessment. Technical Report Series No. 20. Canberra: Food Standards Australia New Zealand. Available on the Internet at: http://www.foodsafety.govt.nz/elibrary/industry/ monosodium_glutamate-science_research.pdf (last accessed on 15 November 2014)

62 The UK Food Standards Agency on Aspartame. Available on the Internet at: http://www.food.gov.uk/science/additives/aspartame/ (last accessed on 15 November 2014).

63 According to Annex III 2.1, foods containing a sweetener or sweeteners authorised pursuant to Regulation (EC) No 1333/2008 must state "with sweetener(s)" accompanying the name of the food.

64 OJ 2010 L $80 / 19$ number of listed foods under the conditions of good manufacturing practices (GMP), as outlined in the Preamble of the Codex GSFA. ${ }^{59}$ The Joint Expert Committee on Food Additives (JECFA) of the United Nations Food and Agriculture Organisation (FAO) and World Health Organisation (WHO), after review of the available scientific literature, ${ }^{60}$ has evaluated MSG with an "Acceptable Daily Intake (hereinafter, ADI) not specified". In 2003, Food Standards Australia New Zealand (FSANZ) reviewed the evidence and concluded that "there is no convincing evidence that MSG is a significant factor in causing systemic reactions resulting in severe illness or mortality". ${ }^{61}$

\section{Aspartame-free}

Aspartame (E951) is an intense sweetener which has been used in soft drinks and other low-calorie or sugar-free foods throughout the world for more than 25 years. ${ }^{62}$ In addition to the general requirement for foods to carry a list of food additives and other ingredients, products containing sweeteners such as aspartame must show the statement "with sweetener(s)" on the label close to the main product name. ${ }^{63}$ Aspartame has been linked in the past to various cancers in the human population. "Aspartame-free" labels have thus flourished in the market on chewing gums, soft drinks, etc.

Regulation (EC) No 1333/2008 of the European Parliament and of the Council on food additives requires that food additives be subject to a safety evaluations by the EFSA before they are permitted for use in the EU. A programme for the re-evaluation of food additives that were already permitted in the EU before 20 January 2009 has been set up under Commission Regulation (EU) No 257/2010 setting up a program for the re-evaluation of approved food additives in accordance with Regulation (EC) No 1333/2008 of the European Parliament and of the Council on food additives. ${ }^{64}$ In the course of the re-evaluation of aspartame, the Panel on Food Additives and Nutrient Sources added to Food (ANS) of the EFSA was asked to deliver a scientific opinion on aspartame as a food additive. Aspartame is a sweetener authorised as a food additive in the EU that was previously evaluated by the Joint FAO/WHO Expert Committee on Food Additives (JECFA), the EU SCF and the EFSA. Both JECFA and SCF established an ADI of $40 \mathrm{mg} / \mathrm{kg}$ body weight $(\mathrm{bw}) /$ day. 
In its opinion of 28 November $2013,{ }^{65}$ the Panel noted there was no epidemiological evidence for possible associations of aspartame with various cancers in the human population. The Panel concluded that aspartame was not a safety concern at the current aspartame exposure estimates or at the ADI of 40 $\mathrm{mg} / \mathrm{kg}$ bw/day. Therefore, there was no reason to revise the ADI of aspartame. Current exposures to aspartame, and its degradation product DKP, were below their respective ADIs. The ADI is not applicable to Phenylketonuria (PKU) patients. In fact, Annex III of the FIR requires in point 2.3 that the wording "contains aspartame (a source of phenylalanine)" must appear on the label on foods containing aspartame in cases where aspartame is designated in the list of ingredients only by reference to the $\mathrm{E}$ number and that "contains a source of phenylalanine" must appear on the label in cases where aspartame is designated in the list of ingredients by its specific name. $^{66}$

Whether EFSA's November 2013 opinion and the re-evaluation of aspartame, as an approved food additive under Regulation (EC) No 1333/2008, will change the negative perception towards aspartame, also created by "free-from aspartame" claims, remains to be seen. It has been argued that EFSA, which said unequivocally that aspartame is safe, has made a meaningful difference, both to NGOs, to governments and even to consumers. ${ }^{67}$

\section{Palm oil-free}

A growing number of food products, to date particularly in France and Belgium, ${ }^{68}$ but increasingly also in other EU Member States, bear "palm oil-free" logos, indicating that palm oil is not contained in the products of different brands and retailers which build advertising campaigns on the systematic denigration and accusation of palm oil. "Palm oil-free" logos on products, often without at least a reference to the nutritional qualities and/or the environmental sustainability of palm oil, must be linked to the large campaigns launched concerning palm oil, especially through Internet websites and other communications. ${ }^{69}$

It is important to note that the labelling of specific vegetable oils (including, inter alia, coconut, palm and sunflower oil) as ingredients in food is only becoming mandatory in the list of ingredients as of 13
December 2014. Although, in principle, all ingredients of a foodstuff must be indicated in the list of ingredients, there were exceptions, such as for vegetable oils. If a product contains palm oil, or sunflower oil, or both, the indication in the list of ingredients that it contains vegetable oil is, until 12 December 2014, sufficient. However, there are important changes in terms of the labelling of the different vegetable oils as ingredients in foodstuffs under the FIR. The FIR no longer allows that the group name "vegetable oil" be used for any vegetable oil without specifying the specific oil(s), which was still permitted under the FIR's predecessor, Directive 2000/13/EC. The application of the new labelling regime was delayed until 13 December 2014 in order to allow time for producers to adjust their labels.

Although the exception for vegetable oils was still included in the legislative proposal of 30 January 2008 for new food labelling rules, ${ }^{70}$ Members of the European Parliament introduced, in an amendment to the proposal during the legislative procedure, the idea that the specific vegetable origin of the vegetable oil contained in foodstuffs should always be declared. ${ }^{71}$ On 1 February 2011, in the position of the Council at first reading, with a view to the adoption of the FIR in relation to the origin of oils and fats, the Council rejected the amendments presented by the European Parliament and noted that more de-

65 EFSA ANS Panel, 2013. Scientific Opinion on the re-evaluation of aspartame (E 951) as a food additive. EFSA Journal 2013;11(12):3496, 263 pp. doi:10.2903/j.efsa.2013.3496.

66 FIR repeals as of 13 December 2014 Commission Directive 2008/5/EC concerning the compulsory indication on the labelling of certain foodstuffs of particulars other than those provided for in Directive 2000/13/EC of the European Parliament and of the Council, OJ 2008 L 27/12.

67 Ben Bouckley, "We're in a better place on aspartame: CocaCola Enterprises boss unshaken by US diet soda slide", BeverageDaily.com, 25 April 2014, available on the Internet at: http:// www.beveragedaily.com/Manufacturers/We-re-in-a-better-place -on-aspartame-Coca-Cola-Enterprises-boss-unshaken-by-US-diet -soda-slide (last accessed on 15 November 2014).

68 Aude Mahy and Filip Pauwels, "Chapter 4 Belgium" in Aude Mahy and Filip Pauwels (ed), Advertising Food in Europe (Berlin: Lexxion, 2014), p. 67 et sqq., at p. 104.

69 For example the French retailer Casino's engagement to withdraw palm oil from 350 products in 2012. Available on the Internet at: http://www.supercasino.fr/Votre-magasin-s-engage.html (last accessed on 15 November 2014).

$70 \operatorname{COM}(2008) 40$ final, Proposal for a Regulation of the European Parliament and of the Council on the provision of food information to consumers.

71 Available on the Internet at: http://www.europarl.europa.eu/sides/ getDoc.do? type $=$ CRE \& reference $=20100615 \&$ secondRef $=$ ITEM $-005 \&$ language $=\mathrm{EN} \&$ ring $=\mathrm{A} 7-2010-0109$ (last accessed on 15 November 2014). 
tailed information than the vegetable origin of the oil would represent further costs for food business operators and would not be justified considering the strengthening of the nutritional information. Despite the Council's opposition, the European Parliament's view succeeded in the end and the amendment was adopted. ${ }^{72}$ The possibility for vegetable oils like palm oil and other oils to be labelled under the neutral category name "vegetable oil" has, therefore, not been included in the FIR.

The first harmonised EU food labelling rules in Council Directive 79/112/EEC on the approximation of the laws of the Member States relating to the labelling, presentation and advertising of foodstuffs for sale to the ultimate consumer ${ }^{73}$ (i.e., the predecessor of Directive 2000/13/EC) established the possibility to use the category name "vegetable oil". The category name was deemed necessary to ensure certain flexibility in the formulations, allowing for the variation in the sourcing and utilisation of the raw material. Different vegetable oils and fats are indeed inter-changeable and inter-changed, depending on seasonal and market availability and on price. The changes to the labelling rules for vegetable oils established in the FIR will inevitably lead (as recognised by the Council itself) to higher manufacturing and labelling costs due to the frequent changes in the composition of products, which need to be reflected in the labels. These costs will most likely be passed on to consumers. It also remains to be seen what impact the new labelling regime under the FIR might have on the current "free-from" campaigns.

72 Available on the Internet at: http://www.europarl.europa.eu/sides/ getDoc.do?type $=$ CRE $\&$ reference $=20100616 \&$ secondRef $=$ ITEM -009 \&language $=E N \&$ ring $=$ A7-2010-0109\#3-294 (last accessed on 15 November 2014).

73 OJ 1979 L 33/1.

74 Actualisation des apports nutritionnels conseillés pour les acides gras, Rapport d'expertise collective "Update on Nutritional Intakes advised regarding Fatty Acids", ANSES May 2011. Available on the Internet at: https://www.anses.fr/sites/default/files/ documents/NUT2006sa0359Ra.pdf (last accessed on 15 November 2014).

75 Donald J. McNamara, Palm oil and Health: A case of Manipulated Perception and Misuse of Science, Journal of the American College of Nutrition, Volume 29, Number 3(S), June 2010.

76 Arne Astrup et al., "The role of reducing intakes of saturated fat in the prevention of cardiovascular disease: where does the evidence stand in 2010?" American Journal of Clinical Nutrition 93 (4): 684-688. January 2011. doi:10.3945/ajen.110.004622.

77 Kalyana Sundram, Ravigadevi Sambanthamurth and Yew-Ai Tan: Palm fruit chemistry and nutrition. Asian Pacific Journal of Clinical Nutrition 2003; 12: 355-362.
In relation to the alleged harmful effects of palm oil, it is often argued that palm oil is very rich in saturated fatty acids compared with other vegetable oils and that it considerably increases cholesterol rates. This appears to be overly simplistic and inaccurate. Indeed, palm oil is rich in saturated fats but, as underlined by the ANSES in its report "Update on $\mathrm{Nu}$ tritional Intakes advised regarding Fatty Acids", recent studies show that consumption of saturated fatty acids does not per se lead to an increase of risk of cardiovascular diseases. ${ }^{74}$ Palm oil is a naturally stable fat that is made up of saturated and unsaturated fat. The saturated fat that it contains, i.e., palmitic acid (C16:) does not contribute to increased serum cholesterol levels when consumed in moderation or in accord with current recommendations for dietary fat/fatty acid consumption. Well endowed with both saturated palmitic (44\%) and monounsaturated oleic $(39 \%)$ fatty acids, palm oil also contains ample quantities of polyunsaturated linoleic acid (10\%). This combination of fatty acids provides an almost ideal mix for the preparation of solid or semi-solid formulations like shortenings or margarines and also, most importantly, it prolongs shelf life for food manufacturers. Switching to, inter alia, partly hydrogenated soybean oil, which contains trans-fatty acids (that palm oil does not contain), increases atherogenic low-density lipoprotein (LDL, the "bad" cholesterol) cholesterol and decreases antiatherodenic high-density lipoprotein (HDL, the "good" cholesterol) cholesterol fractions in the blood. ${ }^{75}$

Therefore, palm oil's positive characteristics are often overseen. Along the same lines, a recent analysis concluded that there is no evidence to show that dietary saturated fat is associated with an increased risk of cardiovascular disease. ${ }^{76}$ The effect of saturated fat should be seen in the context of a person's overall diet. An important consideration is that not all saturated fats are equal in their cholesterolaemic effects. Less certain is also the comparative hypercholesterolaemic behaviour of the different oils and fats that are often termed as saturated, yet contain significant amounts of both monounsaturated and polyunsaturated fatty acids like palm oil. ${ }^{77}$ In addition, it must be recalled that consumption of fatty acids is necessary for the good functioning of the human organism, and that what causes problems in this regard is not the consumption of a single component, but an overall unbalanced diet. Palm oil also contains protective active antioxidants, beta carotene and vitamin 
E, which have cholesterol lowering and antioxidant properties.

It is interesting to see that the same debate about "free from" claims and the nutritional properties of palm oil took place more than 20 years ago in the US and that "free from palm oil" claims and campaigns were stopped. ${ }^{78}$

It is often argued that oil palm cultivation leads to deforestation; that palm oil production damages biodiversity and contributes to endangering certain animal species, in particular the orang-utan; and that palm oil production leads to massive carbon emissions.

Available data show that forestry land in Southeast Asia, which is the primary location in the world where palm oil is grown, decreased between 2000 and 2008 by 13.1 million hectares, while oil palm plantations increased by only 2.9 million hectares. ${ }^{79}$ It is, therefore, clear that other land uses, such as urbanisation or development of infrastructures, are responsible for their proportional part of deforestation and that Malaysia's and Indonesia's palm oil industries are not the culprits. ${ }^{80}$ Moreover, additional data show that land clearing in Indonesia, the leading palm oil

78 In the 1980s, there were various campaigns against palm oil in the US, mostly by the American Soybean Association (hereinafter, ASA). When the US Congress was considering the adoption of the Nutrition Labelling and Education Act of 1990 (hereinafter, NLEA), the ASA lobbied for the use of "no palm oil" labels on food products. ASA's efforts failed, and the legislation was adopted without provisions of this sort. The FDA even sent out warning letters to companies who used "no palm oil" labels on baked goods containing saturated or hydrogenated fats and oils, stating that the labels were false and misleading, and thus a violation of $\S 403(\mathrm{a})(1)$ of the Federal Food, Drug and Cosmetic Act. After the adoption of the NLEA, more campaigns were launched against palm oil. The FDA eventually adopted 21 C.F.R. \$101.13, under which claims such as "no palm oil" are not allowed, absent preapproval under 21 C.F.R. \$101.69. According to 56 Fed. Reg. 60421-01 at 60423, the FDA reasoned that "claims such as "contains no palm oil" and "made with $100 \%$ vegetable oil," convey an implied message that the product is low in, or free of, saturated fat. Therefore, FDA defined an implied nutrient content claim in $\$ 101.13(b)(2)$ as any claim that describes the food, or an ingredient therein, in a manner that implies that a nutrient is absent or present in a certain amount or that may be useful to consumers in selecting foods that are helpful in achieving a total diet that conforms to current dietary recommendations (e.g. "healthy"). Links to FDA guidance available on the Internet at: http://www.fda.gov/Food/GuidanceRegulation/

GuidanceDocumentsRegulatorylnformation/LabelingNutrition/ ucm064908.htm (last accessed on 15 November 2014).

79 Food and Agriculture Organisation, 2009, ResourceStat, FAO statistical database on resources cited in: World Growth, Green Papers: Issue IV "Caught Red Handed: The Myths, exaggerations and Distortions of Greenpeace, Friends of the Earth and Rainforest Action Network, The Campaigns Against South-East Asia's Poor, Mai 2010. Available on the Internet at: http://worldgrowth .org/site/wp-content/uploads/2012/06/WG_Green_Paper_Caught _Red_Handed_5_10.pdf (last accessed on 15 November 2014). producing country, decreased from an average of 1.9 million hectares/year between 1990 and 2000, to an average of 0.5 million hectares/year between 2000 and 2010. ${ }^{81}$ In the key findings for the 2010 Global Forest Resource Assessment, the UN Food and Agriculture Organisation revealed that Indonesia had dramatically reduced its rate of deforestation between 2000 and 2010. ${ }^{82}$ In Malaysia, the trends in forest extension are stable, from an "annual change rate" average of 79,000 hectares/year between 1990 and 2000, to an average of 140,000 hectares/year between 2000 and 2005 and an average of 87,000 hectares/year between 2000 and $2010 .{ }^{83}$ Indonesia has $60 \%$ of the total land area designated as forest (although some of that is production forest, not permanent forest) and has recognised the need to retain forest cover and has made commitments to that end. ${ }^{84}$ Malaysia maintains over $50 \%$ of its land area under forest cover in perpetuity, as it committed to in the 1992 United Nations Conference on Environment and Development (UNCED) held in Rio de Janeiro, and reiterated at the 2009 United Nations Framework Convention on Climate Change (UNFCCC) celebrated in Copenhagen. ${ }^{85}$ Also, Malaysia has already designated more than 5

80 Food and Agriculture Organisation, 2009, ResourceStat, FAO statistical database on resources cited in World Growth, "Palm Oil: The Sustainable Oil", September 2009.

81 Food and Agriculture Organisation, 2010, The Global Forest Resources Assessment 2010, March 2010. Available on the Internet at: http://www.fao.org/forestry/fra/fra2010/en/ (last accessed on 15 November 2014); World Growth, Green Papers: Issue IV "Caught Red Handed: The Myths, exaggerations and Distortions of Greenpeace, Friends of the Earth and Rainforest Action Network, The Campaigns Against South-East Asia's Poor, Mai 2010. available on the Internet at: http://worldgrowth.org/ site/wp-content/uploads/2012/06/WG_Green_Paper_Caught_Red _Handed_5_10.pdf (last accessed on 15 November 2014).

82 FAO publishes key findings of global forest resources assessment, 25 March 2010. Available on the Internet at: http://www.fao.org/ news/story/en/item/40893/icode/ (last accessed on 15 November 2014).

83 Food and Agriculture Organisation, 2010, The Global Forest Resources Assessment 2010, March 2010. Available on the Internet at: http://www.fao.org/forestry/fra/fra2010/en/ (last accessed on 15 November 2014)

84 Food and Agriculture Organisation, 2009, ResourceStat, FAO statistical database on resources cited in: World Growth, Green Papers: Issue IV "Caught Red Handed: The Myths, exaggerations and Distortions of Greenpeace, Friends of the Earth and Rainforest Action Network, The Campaigns Against South-East Asia's Poor, Mai 2010. Available on the Internet at: http://worldgrowth .org/site/wp-content/uploads/2012/06/WG_Green_Paper_Caught _Red_Handed_5_10.pdf (last accessed on 15 November 2014).

85 Ministry of Natural Resources and Environment (2011), Second National Communication to the UNFCCC. Available on the Internet at: http://unfccc.int/resource/docs/natc/malnc2.pdf (last accessed on 15 November 2014) 
million hectares of its forested land as protected area, covering watershed protected areas, wildlife sanctuary, and totally protected forest areas that account for $15.3 \%$ of its land area. ${ }^{86}$ Following ratification of the Convention on Biological Diversity in 1994, Malaysia has been reported to fully meet its 2010 target requirement of conservation of $10 \%$ of national biodiversity. ${ }^{87}$

When compared with other oils that currently also contribute to meet the major world supply and demand for vegetable oils, namely soy bean oil, sunflower oil and rapeseed oil, palm oil proves to be the most effective and efficient. An examination of the input-output ratio regarding palm oil reveals that, using a lower amount of raw material, higher results are delivered, especially when compared to the input-output ratio of other vegetable oils. As a perennial crop, oil palm allows for the production of six to ten times more tonnes of oil per hectare per year (hereinafter, $\mathrm{t} / \mathrm{ha} / \mathrm{yr}$ ) than the annual oil crops. In particular, oil palm has proven to yield ten times (3.68 t/ha/yr) more than soy bean (o.36 t/ha/yr); six times more than rapeseed ( $0.59 \mathrm{t} / \mathrm{ha} / \mathrm{yr})$; and almost nine times more than sunflower $(0.42 \mathrm{t} / \mathrm{ha} / \mathrm{yr}){ }^{88} \mathrm{It}$ follows that, in order to produce the same amount

86 Convention on Biological Diversity - Country Profile: Malaysia. Available on the Internet at: http://www.cbd.int/countries/profile/ ?country=my\#status (last accessed on 15 November 2014).

87 Id.

88 Dr. Yusof Basiron (2012), Malaysian Responsible Palm Oil Assuring Sustainable Supply of Oils \& Fats Into the Future, presented at the Palm Oil Trade Fair \& Seminar China 2012. Available on the Internet at: http://www.mpoc.org.my/upload/P4 _TanSriDatukDr_YusofBasiron_POTSChina2012.pdf (last accessed on 15 November 2014).

89 Data retrieved from FAOSTAT: http://faostat.fao.org/site/567/ DesktopDefault.aspx?PagelD=567\#ancor (last accessed on 15 November 2014).

90 Keith Boyfield, Dispelling the myths: Palm oil and the environmental lobby; Adam Smith Institute. Available on the Internet at: http://www.adamsmith.org/sites/default/files/resources/Dispelling -the-myths.pdf (last accessed on 15 November 2014).

91 See: World Bank, Forest area (\% of land area). Available on the Internet at: http://data.worldbank.org/indicator/AG.LND.FRST.ZS (last accessed on 15 November 2014).

92 Orang-Utan Conservation Colloquium 2009, retrieved from "2009 Yearly Report Kinabatangan Orang-Utan Conservation Project". Available on the Internet at: http://www.hutan.org.my/ (last accessed on 15 November 2014).

93 The IUCN Red List of Threatened Species: Pongopygmaeus (Bornean Orangutan). Available on the Internet at: http://www.iucnredlist.org/apps/redlist/details/17975/0/ (last accessed on 15 November 2014); Juliane Reinecke et al, Palm Oil Under Discussion: The Pros and Cons of an Agricultural Raw Material in Sustainable Food Production, June 2011. Available on the Internet at: http://papers.ssrn.com/sol3/papers.cfm?abstract_id $=1856409$ (last accessed on 15 November 2014). of oil, a much larger amount of rapeseeds, and soy bean and sunflower oilseeds, as compared to palm fruit, would need to be used. The top countries harvesting those oilseeds are not Southeast Asian countries, despite the latter being the usual targets of environmental campaigns. Available data show that, for the 2010 period, the top soy bean harvesting counties were Argentina, Brazil, Canada, China, India, Paraguay, the Russian Federation, Ukraine and the US; the top sunflower harvesting counties were Argentina, the Russian Federation and Ukraine; and the top harvesting rapeseed countries were Australia, Canada, Chile, France, Germany and India. ${ }^{89}$ No allegations are made against any other oilseed harvesting country, where even larger amounts of land are similarly deforested and used for plantation purposes.

In fact, the extent of forested areas in Malaysia and Indonesia is in sharp contrast with that of the United Kingdom, which amounts to only $11.9 \%$ of its territory (much less, if excluding Scotland and Wales). France enjoys $29 \%$ of its territory under forest cover, while in the case of Germany it is $31.7 \%$. However, none of those comes even close to the extent of forested areas in Malaysia, which amounts to $62.3 \%$ of its territory. ${ }^{90}$ The World Bank estimated that Indonesia had over 50\% total forest cover in 2011, compared to around $33 \%$ in the US. ${ }^{91}$ In this light, it is particularly misleading that Malaysia and Indonesia are the primary or sole targets of environmental campaigns against deforestation, particularly when such campaigns are triggered by organisms from countries where deforestation is proven to be remarkably higher. It is therefore simplistic and inaccurate to point at oil palm cultivation as the sole or principal cause of deforestation, inasmuch as multiple other factors need to be considered; and in turn, for the same reason, to exclusively attribute to deforestation the loss of biodiversity in the tropical areas.

A recurrent argument for the denigration of palm oil is that it contributes to endangering several animal species, in particular the orang-utan. However, research shows that palm oil production poses no single primary threat to orang-utan populations in Southeast Asia, which are instead menaced by issues such as habitat fragmentation, poaching, hunting and poor enforcement of local laws. ${ }^{92}$ Further studies have classified the Borneo orang-utan as "critically endangered", yet not as "threatened with extinction" as it is often claimed by NGO campaigns. ${ }^{93}$ 
A number of schemes are in place in Malaysia and Indonesia so as to ensure that palm oil is produced in a sustainable and environmentally respectful manner. Inter alia, these schemes ensure that animals, as well as vegetable species and biodiversity, are not harmed by the process of palm oil production. The instruments in place range from general voluntary certification schemes (such as the Roundtable on Sustainable Palm Oil, hereinafter, $\mathrm{RSPO}^{94}$ certification), to mandatory governmental schemes, such as the schemes of the ISPO (Indonesian Sustainable Palm $\mathrm{Oil}^{95}$ ) and the MSPO (Malaysian Sustainable Palm $\left.\mathrm{Oil}^{96}\right)$. The statement that palm oil production is responsible for the disappearing of the orang-utan is an oversimplified argument directed at dissuading consumers from consuming palm oil, by purely aiming at a common sensitive spot. In 2005, the UNEP stated that the greatest threat to the Great Apes, including the Orang-utan, was poverty. ${ }^{97}$

It is commonly claimed that palm oil cultivation releases enormous amounts of greenhouse gas emissions, either by peat degradation or deforestation. However, it has been found that palm oil is the most efficient feedstock, even when taking into consideration the emissions caused by peat land cultivation ${ }^{98}$. When applying the Life Cycle Assessment methodology to the measuring of carbon emissions released during the production of palm oil, results indicate that, when compared to other vegetable oils, palm oil produces 1,249 kg CO2/tonne. Rapeseed oil produces 1,236 kg CO2/tonne; soybean oil produces $996 \mathrm{~kg}$ $\mathrm{CO} 2 /$ tonne; sunflower oil produces $1,573 \mathrm{~kg}$

94 Roundtable on Sustainable Palm Oil (RSPO) website. Available on the Internet at:

http://www.rspo.org/file/rspo_palmoil_infographic_dec12.jpg (last accessed on 15 November 2014).

95 Available on the Internet at: http://www.ispo-org.or.id/index.php ?lang=en (last accessed on 15 November 2014).

96 MSPO acceptance at international level a challenge to ministry, 3 April 2014. Available on the Internet at: http://www.theborneopost .com/2014/04/03/mspo-acceptance-at-international-level-a -challenge-to-ministry (last accessed on 15 November 2014).

97 UNEP World Conservation Monitoring Centre, "Poverty will make the Great Apes History", 1 September 2005. Available on the Internet at: http://www.unep.org/Documents.Multilingual/Default .asp? DocumentID $=452 \&$ ArticlelD $=4915 \& \mid=e n$ (last accessed on 15 November 2014).

98 "Global Trade and Environmental Impact of the EU Biofuels Mandate" (2010). Study elaborated by the International Food Policy Institute (IFPRI) for the Directorate General for Trade of the European Commission. Available on the Internet at: http://trade.ec .europa.eu/doclib/docs/2010/march/tradoc_145954.pdf (page 64) (last accessed on 15 November 2014).
$\mathrm{CO} 2 /$ tonne; and canola oil produces $1,120 \mathrm{~kg}$ $\mathrm{CO} 2 /$ tonne. $^{99}$ Independent research shows that Indonesian palm oil produces around 38 grams of carbon dioxide per megajoule of energy, about half that of gasoline. ${ }^{100}$

In light of the aforementioned facts, "negative claims" against palm oil must be properly assessed against the available scientific evidence. In particular, the results yielded by scientific studies, indicating that palm oil is more beneficial than alternative vegetable sources, are to be taken into consideration, as well as the precise characteristics of palm oil and the environmental impact of palm oil production. In addition, the particularities of oil palm plantations regarding carbon emissions sequestration, as well as those concerning the actual palm fruit, must be taken into account.

Palm oil is used in a number of consumer goods, generating significant export revenues and, as a traded commodity, its prices and derivatives contribute to increasing the welfare of the urban poor. ${ }^{101} \mathrm{In}$ Indonesia particularly, and as compared to other commonly grown agricultural products, palm oil production stands to bring substantial benefits to smallholders mainly due to its higher returns to land and labour. ${ }^{102}$

In light of the above, the "palm oil-free" campaigns linked to products on which a "palm oil-free" logo is affixed appear to be deceptive or unsubstantiated generalisations and aimed at denigrating competing palm oil and/or promoting certain products by implying that whatever is used as an alternative ingre-

99 J.M. Van Zutphen et al. (2011). LCl comparisons of five vegetable oils as feedstock for biodiesel. Journal of Oil Palm \& The Environment, 2:25-37.

100 Data from the UK Government Department of Transport. Available on the Internet at: www.dft.gov.uk/pgr/roads/environment/rtfo/govrecrfa.pdf (last accessed on 15 November 2014). The UNEP study "Guidance on the Process for selecting alternatives to hcfcs in foams" is available on the Internet at: http://www.unep.fr/ ozonaction/information/mmcfiles/7435-e-foam_.pdf (last accessed on 15 November 2014).

101 "The World Bank Group Framework and IFC Strategy for Engagement in the Palm Oil Sector"; World Bank and International Finance Corporation (2011). Available on the Internet at: http://www.ifc.org/wps/wcm/connect/ 159dce004ea3bd0fb359f71dc0e8434d/ WBG+Framework+and+IFC+Strategy_FINAL_FOR+WEB.pd ?MOD=AJPERES (last accessed on 15 November 2014).

102 "Taking the pulse of the planet: connecting science with policy", UNEP Global Environmental Alert Service (2011). Available on the Internet at: http://www.unep.org/pdf/Dec_11_Palm _Plantations.pdf (last accessed on 15 November 2014). 
dient to palm oil is better, healthier or environmentally greener than palm oil.

\section{Assessment of voluntary negative claims}

The question is whether voluntary "negative claims" emphasising that a product does not include a specific ingredient or nutrient are legal. Out of the examples described above, the case of palm oil is different from the chemical used in food packaging materials BPA, the flavour enhancer MSG and the sweetener aspartame, inasmuch as there are no food safety issues related to palm oil, which can be considered a nutrient when the "free-from" claim is made in a nutritional context.

\section{Not permitted "palm oil-free" nutrition claim}

A front of the pack statement on a food product, which states "palm oil-free", appears to be a not permitted nutrition claim in the sense of Article 8(1) of Regulation (EC) No 1924/2006, which provides that "nutrition claims shall only be permitted if they are listed in the Annex and are in conformity with the conditions set out in this Regulation". Under Article 2(2)(4) of Regulation (EC) No 1924/2006 "nutrition claim means any claim which states, suggests or implies that a food has particular beneficial nutritional properties due to (a) the energy (calorific value) it (i) provides; (ii) provides at a reduced or increased rate; or (iii) does not provide; and/or (b) the nutrients or other substances it (i) contains; (ii) contains in reduced or increased proportions; or (iii) does not contain". Article 2(2)(2) of Regulation (EC) No 1924/2006 defines nutrient as "protein, carbohydrate, fat, fibre, sodium, vitamins and minerals listed in the Annex to Directive 90/496/EEC, and sub-

\footnotetext{
103 OJ 1990 L 276/40.

104 This definition is also found in point 2 of Annex I of the FIR.

105 Arguably, it could even be claimed that some consumers understand such claim as meaning that the product contains no fat or oil at all.

106 Wolfgang Voit/Markus Grube. Lebensmittelinformationsverordung, Kommentar, C.H.Beck 2013, Art. 7, 332-333.
}

stances which belong to or are components of one of those categories". Article 2(1)(c) of Regulation (EC) No 1924/2006 states that, for purposes of this Regulation, the definitions of nutrition labelling, protein, carbohydrate, sugars, fat, saturates, monounsaturates, polyunsaturates, and fibre set out in Council Directive 90/496/EEC on nutrition labelling for foodstuffs ${ }^{103}$ shall apply. Article 1(4)(f) of Directive 90/496/EEC defines fat as "total lipids, and including phospholipids". ${ }^{104}$

Palm oil is a lipid, made up of saturated, monounsaturated and polyunsaturated fatty acids. Therefore, the logo "palm oil-free" suggests that the product in question does not contain the lipid palm oil, ${ }^{105}$ a statement which is to be considered a nutrition claim in relation to the absence of the nutrient "fat", as defined in Directive 90/496/EEC. The "palm oilfree" claim is not listed in the exhaustive list in the Annex and it is, arguably, not a permitted nutrition claim.

It might be argued that the "palm oil-free" label is technically not a nutrition claim, but just a claim informing about the absence of an ingredient. In this case the overall context of the claim needs to be taken into consideration. "Palm oil-free" claims are often accompanied by statements that palm oil's consumption is linked to cardiovascular diseases and that palm oil should better not consumed, guaranteeing to consumers products that are marketed as healthier. These allegations are made on the food packaging itself or not directly on the packaging, but in related communications and/or website statements made by retailers and manufacturers. It can, therefore, be argued that, even if palm oil is deemed an ingredient and not a nutrient of a food, the provisions of Regulation (EC) No 1924/2006 still apply, when the "palm oil free" claim is made in a nutritional context (i.e., challenging its nutritional appropriateness). The listed claim "contains [Name of the nutrient or other substance]" opens the door of the exhaustive list for "other substances", defined in Article 2(2)3) of Regulation (EC) No 1924/2006 as "substances other than nutrients that have a nutritional or physiological effect". ${ }^{106}$ An analogy to "contains" could be established for "free from" as there is a legal gap and a similar situation, since Article 5(1)(b)(ii) of Regulation (EC) No 1924/2006 on the general conditions for nutrition and health claims refers to both the presence and absence of a nutrient or other substance for which the claim is made in food. 


\section{Administrative practice in some EU Member States on nutrition claims}

With this respect, it appears useful to refer to the in terpretation held by French, British, German and Belgian administrative authorities, in order to establish that the "palm oil-free" claim constitutes a nutrition claim within the meaning of Regulation (EC) No 1924/2006. The French authorities responsible for market surveillance of food products have estimated that, depending on the context of communication where the allegation takes place, in some cases, the claim may fall within the scope of application of Regulation No 1924/2006: "it is accepted that emphasising the lack of an ingredient may, in some cases and depending on the context of communication, be assimilated to a nutritional valorisation of the product". ${ }^{107}$

In a document entitled "Guidance to compliance with Regulation (EC) 1924/2006 on nutrition and health claims made on foods", ${ }^{108}$ the British Department of Health affirms that allegations only indicating the presence or absence of an ingredient, which has not been included, increased or withdrawn, with a view to highlight a beneficial effect, whether nutritional or on health, to develop a nutritional or health function in the foodstuff, or to improve the nutritional profile of the final product, may be considered as not falling within the scope of Regulation No $1924 / 2006$, unless they are presented in a manner that suggests consumers that the foodstuff possesses beneficial nutritional proprieties.

When affirming that, by eliminating palm oil, the products are healthier, the "palm oil-free" claim is arguably presented in a manner that allows consumers to believe that the competitor's products possess beneficial nutritional proprieties. The UK Food Standards Agency has issued another guidance document ${ }^{109}$ to assist manufacturers, producers, retailers and caterers to decide when certain descriptions may be used and when they should not. Under point 62, these guidelines state that other claims (which might be termed "negative claims") that do not use the term "natural" or its derivatives directly, but the effect of which is to imply "naturalness" to the consumer, are potentially misleading and confusing and should therefore not be used, inter alia, when an ingredient or an additive of another category having broadly similar effect has been used. Here, it could be argued that a "negative claim" stating "palm oil-free" must not be used when another vegetable oil, that has broadly similar effects, is used.

In Germany, a similar position has been adopted by the ALS in its opinion No. $2011 / 50^{110}$ on a "hydrogenated fats-free and oil-free" claim on margarine. The question posed concerned whether this claim constituted an illicit nutrition claim. The ALS concluded that it constituted a nutrition claim within the meaning of Article 2(2)(4b)iii of Regulation No 1924/2006, since the allegation at hand informed consumers of the absence of a nutritional element considered critical. The allegation was, therefore, not authorised, since it was not listed in the Annex of Regulation No 1924/2006. Such opinion of the ALS applies perfectly to the "palm oil-free" claims, presented in the overall context as an alleged critical substance from a nutritional point of view.

When the context of a claim refers to the nutritional benefit of the product, the Belgian authorities consider that a "palm oil-free" claim falls under Regulation No 1924/2006, having the same significance to consumers as the nutrition claim "low saturated fat", meaning that a product which claims to be "palm oil-free" must, in addition to being free of palm oil, also contain a maximum of $1.5 \mathrm{~g}$ of saturated fatty acids and trans-fatty acids per $100 \mathrm{~g}$ and the sum of saturated fatty acids and trans-fatty acids must not provide more than $10 \%$ of energy. ${ }^{111}$

In conclusion, according to the above-mentioned EU Member States' interpretations, when made in a nutritional context, a "palm oil-free" claim must be considered a nutrition claim and the provisions of Regulation (EC) No 1924/2006 apply.

107 Statement relating to "palm oil-free" logos by a DDPP (Directions départementales de la protection des populations) of 24 January 2013, later confirmed by the DGCCRF (Direction générale de la concurrence, de la consommation et de la répression des fraudes).

108 Version 2, November 2011. Available on the Internet at: https:// www.gov.uk/government/uploads/system/uploads/attachment _data/file/204320/Nutrition_and_health_claims_guidance November_2011.pdf (last accessed on 15 November 2014).

109 Criteria for the use of the terms fresh, pure, natural etc. in food labelling (Revised in July 2008). Available on the Internet at: http://www.food.gov.uk/sites/default/files/multimedia/pdfs/ markcritguidance.pdf (last accessed on 15 November 2014).

110 The opinion of the ALS ("ALS Stellungnahmen" in German) is available on the Internet at: http://www.bvl.bund.de/SharedDocs/ Downloads/01_Lebensmittel/ALS_ALTS/ALS_Stellungnahmen_98 _Sitzung_2011.pdf?_blob=publicationFile \& $v=2$ (last accessed on 15 November 2014).

111 Aude Mahy and Filip Pauwels, "Chapter 4 Belgium" in Aude Mahy and Filip Pauwels (ed), Advertising Food in Europe (Berlin: Lexxion, 2014), p. 67 et sqq., at p. 104. 


\section{Misleading claims}

Another legal issue that must be analysed in respect of the different "free-from" claims is to see whether these manufacturers' labels comply with EU law on misleading advertising and unfair labelling practices. As of 13 December 2014, the provision on misleading advertising in general food labelling law will change. Article $7(1)$ of the FIR (on fair information practices) provides that food information shall not be misleading, particularly: "(c) by suggesting that the food possesses special characteristics when in fact all similar foods possess such characteristics, in particular by specifically emphasising the presence or absence of certain ingredients and/or nutrients". The reference to "absence" is more specific than $\mathrm{Ar}$ ticle 2(1)(a) of Directive 2000/13/EC on the labelling of foodstuffs. Article 36(2) of the FIR provides that food information provided on a voluntary basis shall: (a) not mislead the consumer, as referred to in Article 7; (b) not be ambiguous or confusing for the consumer; and (c) where appropriate, be based on the relevant scientific data. But does Article $7(1)$ (c) of the FIR address "negative claims"? Emphasising the absence of certain ingredients and/or nutrients may well address the case of "negative claims". However, it appears that the legislator had the case in mind when a claim states "aspartame-free" or "palm oilfree", when in fact the product contains these substances and consumers are misled about this fact. In other words, Article 7(1)(c) of the FIR does not appear to address "negative claims" with an implied message.

A provision on misleading advertising is also provided in Article 3 of Regulation (EC) No 1924/2006, which (in the relevant part) provides that the use of nutrition and health claims shall not: (a) be false, ambiguous or misleading; (b) give rise to doubt about

\footnotetext{
112 OJ 2006 L 376/21.

113 See Case C-362/88 GB-INNO-BM [1990] ECR I-667; Case C-238/89 Pall [1990] ECR I-4827; Case C-126/91 Yves Rocher [1993] ECR I-2361; Case C-315/92 Verband Sozialer Wettbewerb [1994] ECR I-317; Case C-456/93 Langguth [1995] ECR I-1737; Case C-470/93 Mars [1995] ECR I-1923) and, in particular, Case C-210/96 Gut Springenheide and Tusky [1998] ECR I-4657, paragraph 31.

114 Case C-303/97 Sektkellerei Kessler [1999] ECR I-513 paragraph 36.

115 Case C-220/98 Estée Lauder [2000] ECR I-117, paragraph 27.

116 Case C-30/99 Commission v. Ireland [2001] ECR I-4619, paragraph 32.
}

the safety and/or the nutritional adequacy of other foods; (e) refer to changes in bodily functions that could give rise to or exploit fear in the consumer, either textually or through pictorial, graphic or symbolic representations.

Under EU law, misleading advertising is defined in Article 2(b) of Directive 2006/114/EC of the European Parliament and of the Council concerning misleading and comparative advertising ${ }^{112}$ as "any advertising which in any way, including its presentation, deceives or is likely to deceive the persons to whom it is addressed or whom it reaches and which, by reason of its deceptive nature, is likely to affect their economic behaviour or which, for those reasons, injures or is likely to injure a competitor".

As it has been shown in the chapters above, scientific evidence does not support concerns about the negative health effects and food safety issues surrounding the flavouring MSG, the sweetener aspartame or palm oil. In relation to BPA, science seems to be divided, but at least for people above three years, there appears to be no risk. Therefore, the respective "free-from" claims may deceive the persons to whom they are addressed and which, by reason of their deceptive nature, are likely to affect their economic behaviour or which, for those reasons, bring injury to a competitor.

In the assessment of whether labelling may be misleading, the European Court of Justice (hereinafter, the Court) has consistently ruled that a uniform standard is to be applied when determining if a purchaser has been misled. ${ }^{113}$ By virtue of this interpretation, the presumed expectations of the average consumer, who is reasonably well-informed and reasonably observant and circumspect, are to be taken into account. This criterion has been applied by the Court in a number of different fields, such as wine brands ${ }^{114}$, cosmetics ${ }^{115}$, or hallmarks. ${ }^{116}$ In order to determine whether an advertising statement is or is not liable to mislead consumers, the Court applies a kind of de minimis reasoning. It only decides that consumers are being misled where it considers that the risk of this happening is sufficiently serious or obvious.

In this case, where the consumer is told through "freefrom" logos and associated campaigns that a product is safer and/or healthier and/or sustainable, it appears sufficiently serious or obvious, and can by no means be excluded, that the average consumer, who is rea- 
sonably well informed and reasonably observant and circumspect, will believe that such products are safer, of better quality and/or of healthier nutritional characteristics than those containing, e.g., BPA, MSG, aspartame or palm oil. This consumer will believe that these latter products are unsafe or of minor quality, which is likely to affect the economic behaviour and choice of the consumer, who will likely opt for other products not containing them. In conclusion, for the reasons seen above, the logos and connected campaigns are likely to injure competitors' products. In any event, normally informed and reasonably attentive and aware consumers cannot be knowledgeable of such facts. Therefore, the "free-from" claim (in context of the campaign) gives rise to doubts in consumers' minds about the safety or nutritional adequacy or sustainability of, respectively, BPA, MSG, aspartame or palm oil, and appears to be misleading.

In 2009, the Higher Regional Court of Hamburg had to decide on the advertising of a medicinal product, ${ }^{117}$ in which the absence of a specific substance was highlighted. Negative effects of the substance could not be proved. The court ruled that the statement, however, suggested such a disadvantage of the substance and was, therefore, misleading. It has been argued that from the case can be inferred that courts - at least the German courts - see the proliferating "free-from" claims as an increasingly critical matter. $^{118}$

Manufacturers and retailers are appealing to the fears and rumours that are circulating about these substances, by advertising products as "free-from" them. The practices engaged into by these companies induce consumers to err, especially regarding the safety, nutritional quality and sustainability of their products and products containing the demonised substances. In that sense, these practices are susceptible of substantially altering the economic behaviour of normally-informed and reasonably-attentive and aware consumers, with respect to products which are not "free-from", which they will reject, and with respect to the products labelled "free-from", which they will perceive as "healthier". It is recalled that the shape, appearance or packaging, the packaging materials used, the manner in which they are arranged and the setting in which they are displayed, and the information that is made available about them, through whatever medium, are, according to Article 16 of Regulation (EC) No 178/2002, relevant in determining whether consumers are misled.

\section{Misleading environmental claim}

It is often argued that "free-from" claims address environmental goals being demanded by consumers. Inter alia, it is argued in the context of a "palm oilfree" claim that "sunflower oil has a better impact on the environment (than palm oil) because it does not contribute to deforestation". Such claim can be considered as an "uncontrolled self-declared environmental claim" or a "green claim". There is no specific EU legislation on these types of claims on foodstuffs. The European Commission has outlined a possible approach at the EU level in order to contribute ensuring that self-claims by economic operators, about the environmental characteristics of products and services supplied, are not misleading and can serve the purpose of promoting more sustainable consumption. ${ }^{119}$

The international standard ISO 14021:1999 sets specifications for making self-declared environmental claims on goods and services. ${ }^{120}$ A definition of self-declared environmental claims can be given as an "environmental claim that is made, without independent third-party certification, by manufacturers, importers, distributors, retailers or anyone else likely to benefit from such claims". The following principles are formulated in the standard: (1) Self-declared environmental claims shall be accurate, verifiable, relevant, able to be substantiated and not misleading; (2) Environmental claims shall be based on a scientific methodology that is sufficiently thorough and comprehensive to support the claim and that produces accurate and reproducible results; (3) Information concerning the procedure, methodology and any criteria used to support environmental claims shall be available and provided upon request to all interested parties; and (4) The formulation of environmental claims shall take into consideration all rele-

117 OLG Hamburg, IIC-RR 2010, 70, Gewerblicher Rechtsschutz und Urheberrecht, GRUR-RR 2010, 70.

118 Wolfgang Voit/Markus Grube. Lebensmittelinformationsverordung, Kommentar, C.H.Beck 2013, Art. 7, 146.

119 European Commission, DG Sanco, Guidelines for Making and Assessing Environmental Claims. Available on the Internet at: http://ec.europa.eu/consumers/cons_safe/news/green/guidelines _en.pdf (Last accessed on 15 November 2014).

120 The standard is available on the Internet at: http://www.iso.org/ iso/catalogue_detail?csnumber $=23146$. Many countries use the standard as a basis to inform national codes and guidance, such as the UK Government in its "Green Claims Guidance" of February 2011 
vant aspects of the life cycle of the goods or service, although not necessarily considering a full life-cycle analysis.

In relation to the possible EU approach in the area of "green claims", 121 the European Commission states that the proliferation of misleading or confusing green claims limits the ability of consumers to act in favour of sustainable consumption through their purchasing choices. Unreliable or misleading green claims limit the potential of serious eco-label schemes, discourage companies to invest in more environmentally friendly products and services and demotivate consumers to look for such "greener" products and services. The approach proposed is framed within, and complements, the general EU regulatory framework on misleading advertising, notably the EU Directive concerning misleading advertising. In general, environmental information must not be misleading. ${ }^{122}$ Certain vague claims, as the ones on the environmental impact of palm oil, could be interpreted as deceptive and, therefore, misleading. However, the European Commission acknowledges that defining what may (or should) be considered deceptive in the field of green claims is complex. As there is currently no specific regulatory framework on such environmental/green claims, the general rules on misleading labelling on food products apply.

Statements on the environmental impact of palm oil production and claims that it contributes to deforestation (or that it does so more than other "like" ingredients), that it damages biodiversity and contributes to endangering certain animal species and that it leads to massive carbon emissions are arguably not accurate, not verifiable and not further substan-

121 Outline of a possible Community approach in the area of "Green Claims" - consultation document. Available on the Internet at: http://ec.europa.eu/consumers/cons_int/safe_shop/fair_bus_pract/ green_pap_comm/studies/green_claim_en.htm (last accessed on 15 November 2014).

122 Wolfgang Voit/Markus Grube. Lebensmittelinformationsverordung, Kommentar, C.H.Beck 2013, Art. 7, 135.

123 Position "L'ANIA déconseille le recours aux communications pejoratives", ETIQ 12-1011 of October 2012. Available on the Internet at: http://www.ania.net/ (last accessed on 15 November 2014). ANIA is the acronym for the French Association Nationale des Industries Alimentaires. ANIA's mission includes keeping consumers duly informed and ensuring that conditions of fair competition are met, while it is fundamental that good communication practices are established and respected by operators.

124 Definition extracted from the Larousse Online Dictionary: "Pejorative: That tends to depreciate or denigrate the person, object or concept it refers to". tiated. Provided that this can be argued and backed by evidence, a possible misleading effect on consumers can again be shown. In this case, it could appear sufficiently serious or obvious that an average consumer, who is reasonably well informed and reasonably observant and circumspect, when reading that, inter alia, sunflower oil does not contribute to deforestation and has a better impact on the environment (than palm oil), may believe that this is true. This consumer will believe that products containing palm oil are bad for the environment, which is very likely to affect the economic behaviour of the consumer when choosing what to buy. In conclusion, for those reasons, such statements injure or are likely to injure competitors using palm oil in their products. These statements give rise to doubt about the environmental impact of palm oil and are arguably misleading.

\section{Private initiatives}

The French National Association of Agro-food Industries (ANIA in its French acronym) has taken a position against "free-from" claims in its opinion "ANIA advises against pejorative communications".123 These recommendations apply to commercial communications coming from a company or a professional sector, appearing on the label or packaging of foodstuffs or the related commercial advertising, as well as claims. The recommendations seek to advise against communications carrying a pejorative ${ }^{124}$ and negative message regarding an ingredient, substance, compound or manufacturing process; and strictly frame the use of allegations informing on its absence. Pejorative communications, especially those based on allegations highlighting the absence or reduction of a substance, in products' presentation, promotion or advertising, contribute to maintain fears and prejudices, as well as fuel unfounded rumours Pejorative communications also contribute to degrade the image of the agro-food industry.

In general, ANIA recommends the agri-food industry not to resort to this type of communication and, instead, to communicate positively. Furthermore, pejorative communications may, in certain legal frameworks, be considered as denigrating statements. Denigration consists of discrediting a competitor by spreading malicious information about it, its products or its services. Such unfair behaviour constitutes 
a fault under French law. ${ }^{125}$ The following may be considered, under certain conditions and regardless of the support used, examples of "denigration": (1) Communications fuelling a negative media environment, or carrying a sanitary or nutritional message concerning an ingredient, compound, substance or process in relation to the safety of which scientific bodies have not issued a contrary position; (2) Communications carrying a negative allegation (e.g., "without [...]"/ "[...] free") associated to a judgement discrediting the ingredient or product at hand; (3) Communications associating the ingredient or product at hand with health risks; and (4) Communications relying on information non-scientifically based, which may give rise to unjustified fears.

In relation to cases of claims on the absence of a specific substance (inter alia, aspartame-free), where the ingredient targeted by the negative claim has been substituted by an ingredient having the same technological role, ANIA considers that, where there is a risk that consumers will be deceived, negative claims may be acceptable on condition that they be completed by a corrective statement informing consumers of the presence of the ingredient of substitution. In order not to induce consumers to error, such statement should appear in a legible manner and within the same field of vision of the label ${ }^{126}$ and in any communication channel. For example, the claim "aspartame-free" on a product containing synthetic sweeteners cannot be accepted unless, in cases where there is a risk that consumers will be deceived, it is completed by a corrective statement on the presence of other sweeteners.

\section{Should legislative and/or regulatory processes be triggered in order to adopt new rules at EU-level in order to prevent these campaigns and harmonise legislation within the EU?}

"Free-from" campaigns targeted at specific operators, which use certain foodstuffs, ingredients or other substances, are clearly detrimental for the relevant industry. By marketing products as "free-from", operators and retailers are playing on consumers' fears with claims, which are almost always not based on sound science (in relation to nutritional and food safety aspects) and information (on environmental sustainability). Too many commercial actors are tak- ing advantage of these "rumours" through deceptive and (as shown above) arguably illegal campaigns.

There are instruments available to fight these campaigns, inter alia, complaints to the respective competent authorities for market surveillance of food labelling and advertising, but EU Member States' administration appears to be overwhelmed by the extent of these campaigns. Rules (on unfair business practices) are there against smear campaigns (or other commercial boycotts), but can be effectively triggered at the courts only when there is urgency and damage can be proved. Arguing at the courts that these campaigns are misleading (and/or, in the case of palm oil, that they constitute illegal nutrition claims) is not straightforward. The burden of proof appears to lie with the operators being targeted by such campaigns, who have to demonstrate that consumers are being misled. There appears to be a grey area in which it is too easy to denigrate competitors by claiming that a product is "free-from" an allegedly harmful and dangerous substance, which competitors are utilising.

This matter is so important and so urgent to be addressed that operators cannot be left with the confrontational instruments of national litigation and/or administrative recourses as the only way to vindicate their rights and try to stop these highly-damaging campaigns. The EU must regulate this area and bring to a stop a phenomenon that distorts competition and takes advantage of a legal loophole. There is a need to require evidence-based labelling and advertising. This could be done by reversing the burden of proof. EU regulators have done so in relation to health claims made on food, where operators have to prove a relation between the claim and the claimed effect on health. Evidence-based labelling has also been required in the new fish labelling rules in Regulation (EU) No 1379/2013 of the European Parliament and of the Council on the common organisation of the markets in fishery and aquaculture prod-

125 Article 1382 of the French Civil Code. Jurisprudence has established that three cumulative conditions must be met in order to find "denigration", i.e.: (i) a company, a group of companies or a sector is identified or identifiable as the target of a malicious critique; (ii) the message is transmitted by any public communication channel; and (iii) the message carries a critique which discredits products or services, and is capable of harming others and/or to capture or divert consumers.

126 The FIR defines "field of vision" as "all the surfaces of a package that can be read from a single viewing point" (Article 2 point 2 $(k)$. 
ucts, ${ }^{127}$ which provides for mandatory and voluntary labelling information. Article 39(4) of Regulation (EU) No 1379/2013 establishes that "no voluntary information shall be included that cannot be verified".

The requirement of evidence-based voluntary labelling would be in line with the general principles on food information established in Article 3 of the FIR, which state that: (1) The provision of food information must pursue a high level of protection of consumers' health and interests by providing a basis for final consumers to make informed choices and to make safe use of food, with particular regard to health, economic, environmental, social and ethical considerations; and (2) The Food information law must aim to achieve in the EU the free movement of legally produced and marketed food, taking into account, where appropriate, the need to protect the legitimate interests of producers and to promote the production of quality products.

The need for evidence-based labelling was already identified in the first drafts for the FIR in late 2007, with the final proposal published in January 2008. ${ }^{128}$ The proposal contains an explicit reference to the White Paper on a Strategy for Europe on Nutrition, Overweight and Obesity of 30 May 2007 (hereinafter, the White Paper) ${ }^{129}$ highlighting consumers' need for "clear, consistent and evidence-based information" and the role that nutrition labelling should play in enabling consumers to make "health conscious food choices" and in supporting balanced diets. ${ }^{130}$ The White Paper also emphasises that "an individual's knowledge, preferences and behaviours, for example related to lifestyle and eating habits, are shaped by the environment around them" and that

\footnotetext{
127 OJ 2013 L 354/1.

128 Proposal for a Regulation of the European Parliament and of the Council on the provision of food information to consumers, 30 January 2008, COM/2008/40 final. See also: Martin Holle, Nutrition Policy in the European Union, Wageningen Working Papers in Law and Governance, Law and governance group 2014/03, p. 37.

$129 \mathrm{COM} / 2007 / 279$ final.

$130 \mathrm{COM} / 2008 / 40$ final, p. 2

131 COM/2007/279 final, pp. 5-6.

132 A new nutrition claim proposed by the European Commission, where appropriate, after consulting the EFSA, may be blocked by the European Parliament and the Council. The European Commission may involve interested parties, in particular food business operators and consumer groups, in order to evaluate the perception and understanding of the claims in question.

133 Wolfgang Voit/Markus Grube. Lebensmittelinformationsverordung, Kommentar, C.H.Beck 2013, Art. 36, 32.
}

"this concerns, on the one hand, access to clear, consistent and evidence-based information when deciding which foods to buy and, on the other, the wider information environment which is in turn shaped by cultural factors, such as advertising and other media". The White Paper further highlights that "a key objective of Regulation (EC) No 1924/2006 is to ensure that nutrition and health claims on foods are based on reliable scientific evidence, so that consumers are not misled by inaccurate or confusing claims" and that "advertising and marketing are powerful sectors that aim to influence consumer behaviour (and there is evidence that advertising and marketing of foods influence diet, and in particular those of children)".'131

One option to address the matter of unsubstantiated "free-from" claims could be adding explicitly "free-from" (similar to the listed "contains" [Name of the nutrient or other substance]) to the exhaustive list of nutrition claims in the Annex to Regulation (EC) No 1924/2006, also addressing implied messages. Article 8(2) of Regulation (EC) No 1924/2006 establishes the procedure for amending the Annex. $^{132}$

A second option may be a delegated act under the FIR. Article 36(2) of the FIR sets out requirements for voluntary food information which shall: (a) not mislead the consumer; (b) not be ambiguous or confusing for the consumer; and (c) where appropriate, be based on the relevant scientific data. Article 36(4) of the FIR establishes that, in order to ensure that consumers are appropriately informed, where voluntary food information is provided by food business operators on a divergent basis, which might mislead or confuse the consumer, the European Commission may, by means of delegated acts provide for additional cases of provision of voluntary food information. It can be argued that the regulation of voluntary "freefrom" claims is necessary because food business operators might mislead or confuse consumers. This is, in fact, not just mere theory, but unfortunately substantiated by considerable evidence with the case of palm oil being the perfect example. It has been argued that measures adopted under paragraph 4 could establish criteria for the non presence of certain meat types ("pork free") or GM-free labels. ${ }^{133}$ A delegated act could be adopted, basically stating that voluntary food information through negative claims must not be misleading, particularly: by deceiving consumers and discrediting products/competitors by claiming 
explicitly on the food packaging or in the overall communication context that the product does not contain a foodstuff, ingredient or nutrient, which is (1) unhealthier without a scientific basis; and (2) less environmentally sustainable without a scientific basis. In view of the colourful and punchy negative claims currently on the market, it could further be established that these claims may only be made either in the list of ingredients, immediately following the replaced ingredient, or in a footnote to this list and that the claims may not be made in size, colour and font that are different from those used for the list of ingredients.

A third option could be the adoption by the European Commission of guidelines addressed to national authorities or "best practices" addressed at operators on negative claims along the same lines than the delegated act described above.

\section{Conclusion}

Informing consumers about, inter alia, the absence of certain ingredients that cause allergies or intolerances is extremely important, but it should also be noted that there is a current trend in food manufacture to "demonise" certain nutrients, ingredients and other substances by claiming that the foodstuffs are "free-from" them, be it palm oil, aspartame or others. The requirements for labelling a foodstuff as "glutenfree" are strictly harmonised at the EU level, but it is only one of few examples of the "free-from" trend, which are regulated, together with labels indicating the absence of certain nutrients, inter alia, fat or sugars in EU legislation on nutrition labelling.

Regulators ought to urgently step in and address market distortions and deceptive or fraudulent practices that, in the name of marketing, often confuse consumers and result in unfair trading practices that distort competition. The most fitting and unfortunate example of this is the proliferation, especially in France and French-speaking countries, of "palm oil-free" labels, which, when made in a nutritional context, are arguably nutrition claims and, as such, to be considered outright illegal under EU law. In addition, similarly to "MSG-free" and "aspartame-free", these "palm oil-free" claims and the implied messages behind them are misleading. The request and expectation of EU Member States' administrative authorities, legal interpreters and commercial operators alike is that EU and EU Member States' legislators and regulators will take labelling seriously and, while they impose costly new rules on producers, they also ensure that consumers are not misled by astute marketing techniques that have no informative agendas, but simply aim at denigrating certain products in order to promote others or to convince consumers that what is "free-from" a certain substance is a better, healthier or greener product. "Free-from" claims (and the implied message behind them) must be based on substantiated evidence and the burden of proof must rest on those using such labels. 